\title{
Convenanten tussen politie en ziekenhuizen
}

\author{
W.L.J.M Duijst
}

- 1. Inleiding

Sinds enkele jaren worden er in Nederland convenanten tussen politie en ziekenhuizen gesloten. De reden voor het totstandkomen van de convenanten is gelegen in het feit dat soms het opsporingsbelang en medisch beroepsgeheim botsen en soms samenwerking tussen hulpverlener en opsporingsambtenaar gewenst is. Bij de botsing tussen opsporing en medisch beroepsgeheim moet gedacht worden aan de arts die wordt geconfronteerd met een bolletjesslikker, de verpleegkundige die een wapen vindt in de kleding van de patiënt, maar ook de arts of verpleegkundige die slachtoffer wordt van geweld door de patiënt of het kind dat wordt mishandeld door zijn ouders. Bij de samenwerking tussen hulpverlener en opsporingsambtenaar moet gedacht worden aan (verkeers)ongevallen en calamiteitenbestrijding. Door het sluiten van convenanten wordt gestreefd naar rechtszekerheid voor zowel patiënten als beroepsbeoefenaren. 
In verschillende wetten is een aantal regelingen opgenomen om "samenwerking” tussen medische hulpverleners en opsporingsambtenaren te stroomlijnen. Zo is in de Wet op de lijkbezorging een regeling opgenomen over hoe te handelen bij een vermoeden van onnatuurlijke dood en is er sinds april 2002 een wettelijke regeling over het melden van euthanasie.

Ook de botsing tussen opsporingsbelang en het (medisch) beroepsgeheim is gedeeltelijk geregeld in de wet. Zo is het verschoningsrecht opgenomen in artikel 218 van het Wetboek van Strafvordering (Sv). In dit wetboek is verder een regeling opgenomen over inbeslagneming (art. 98 lid 1Sv), doorzoeking (art. 98 lid 2 Sv) en het vernietigen van gegevens in beslag genomen of opgenomen (door middel van een telefoontap) bij een verschoningsgerechtigde (art. 126aa lid $2 \mathrm{~Sv})$.

Het beginsel dat aan de genoemde regelingen ten grondslag ligt is dat het medisch beroepsgeheim in principe voorrang heeft op het opsporingsbelang. In het Wetboek van Strafvordering en in de jurisprudentie zijn op deze regel uitzonderingen geformuleerd. Een voorbeeld hiervan is de in het Wetboek van Strafvordering opgenomen regel dat geschriften die onder het verschoningsrecht vallen niet in beslag genomen kunnen worden (art. 98 Sv). Deze wettelijke regeling 
impliceert dat andere voorwerpen bij verschoningsgerechtigden wel in beslag kunnen worden genomen. ${ }^{1}$

Dit

is de eerste uitzondering op het principe dat het beroepsgeheim prevaleert boven opsporing. Bovendien is door de Hoge Raad geconcludeerd dat in uitzonderlijke gevallen van de regel, dat geschriften bij verschoningsgerechtigden niet in beslag kunnen worden genomen, kan worden afgeweken. Is de verschoningsgerechtigde verdachte van een ernstig strafbaar feit dan is inbeslagneming van geschriften volgens de Hoge Raad wel mogelijk. ${ }^{2}$

Dit is de tweede uitzondering op het genoemde beginsel.

De wettelijke regelingen lijken niet helemaal te voldoen in de praktijk; botsingen en onduidelijkheden blijven voorkomen. De botsingen leiden regelmatig tot boeiende jurisprudentie. ${ }^{3}$

Om de contacten tussen opsporingsambtenaren en ziekenhuizen te vergemakkelijken en daarmee conflicten tussen opsporingsambtenaren en ziekenhuizen te voorkomen worden er, zoals gezegd, afspraken tussen 
politie en ziekenhuizen gemaakt; deze afspraken worden vastgelegd in convenanten.

Zo zijn er convenanten tussen ziekenhuizen en politie (en justitie), tussen ambulancezorg en politie en binnen jeugdnetwerken (consultatiebureaus, politie, bureau jeugdzorg en anderen).

In het hier beschreven onderzoek worden de convenanten tussen politie en ziekenhuizen, zoals die bestaan in Nederland, met elkaar vergeleken.

De convenanten binnen de ambulancezorg worden buiten beschouwing gelaten, voorzover het convenanten betreft tussen alleen ambulancezorg en politie. ${ }^{4}$

Dit vanwege het feit dat deze convenanten op een andere manier tot stand komen dan de convenanten tussen politie en ziekenhuizen. De convenanten tussen politie en ziekenhuizen zijn tot stand gekomen vanuit lokale initiatieven. Deze lokale initiatieven hebben navolging gevonden. Van een coördinatie van deze initiatieven is geen sprake. De convenanten tussen ambulancezorg worden gecoördineerd door SOVAM (Sectorfonds voor ambulancezorg) .5 
SOVAM brengt

een richtlijn uit. Deze richtlijn is tot stand gekomen in samenwerking met en van goedkeuring voorzien door de beroepsvereniging ambulancezorg, het korpsbeheerdersberaad, het openbaar ministeriepolitieberaad, de raad van hoofdcommissarissen en het college van procureurs-generaal. Het streven is dat alle instellingen voor ambulancezorg de richtlijn gaan volgen.

Na een algemene inleiding inzake convenanten zullen de verschillende convenanten, zoals die bestaan in Nederland, inhoudelijk met elkaar worden vergeleken. Vervolgens zal een kritische noot bij de convenanten geplaatst worden en zal worden besproken wat de consequenties (kunnen) zijn van het maken van convenanten tussen politie en ziekenhuizen.

\section{- 2. Convenanten}

Er bestaat geen specifieke wettelijke regeling voor convenanten. Door de wetgever wordt dit ook niet noodzakelijk geacht. ${ }^{6}$

Convenanten zijn een vorm van zelfregulering.

Volgens Polak is kenmerkend voor zelfregulering dat de betrokkenen zelf tot regelgeving komen en dat die regels anders zijn dan de "gewone" regelgeving door regelgevers 
die hun bevoegdheid ontlenen aan de Grondwet. ${ }^{7}$

Convenanten zijn schriftelijke afspraken tussen minimaal twee partijen waarvan er minstens een tot de overheid behoort, strekkende tot verwezenlijking van overheidsbeleid. ${ }^{8}$

Ervan uitgaande dat in de convenanten regels worden vastgelegd die gelden voor beide partijen vallen convenanten gedeeltelijk onder zelfregulering en gedeeltelijk onder overheidsregulering.

\section{Waarom zelfregulering?}

De redenen om voor zelfregulering te kiezen kunnen variëren. Ten eerste kan er sprake zijn van onvrede met de wetgeving als reguleringsproces. Van wetgeving kan gezegd worden dat het over het algemeen een traag instrument is. Ook zijn er aan het maken van een formele wet vele regels verbonden. Het gevolg is dat wetgeving over het algemeen in een laag tempo achter de maatschappelijke feiten aanloopt. Dit kan leiden tot 
ongeduld in het veld. ${ }^{9}$

Zelfregulering kan een uitkomst

bieden ter overbrugging van de periode dat de wetgeving op zich laat wachten. ${ }^{10}$

De tweede reden om te komen tot zelfregulering kan liggen in het feit dat het te regelen onderwerp zeer complex is en moeilijk in wetgeving te vatten. Regulering kan dan slechts tot stand komen met kennis en ervaring uit het veld. Ten derde kan zelfregulering ook tot stand komen omdat de wetgever expliciet in een wettelijke regeling de verplichting opneemt om tot zelfregulering te komen. ${ }^{11}$

Ten slotte kan zelfregulering een manier zijn om regulering door de overheid te voorkomen. ${ }^{12}$ 
De verschillende redenen om te komen tot zelfregulering hangen met elkaar samen en lopen vaak in elkaar over. De keuze voor zelfregulering heeft alles te maken met het gebruik van open normen en de mate van complexiteit van de te regelen materie. Het gebruik van open normen door de wetgever nodigt de groepen waarop deze normen betrekking hebben uit tot het geven van invulling aan die norm. Daar komt bij dat het exact invullen van bepaalde normen door de wetgever vrijwel onmogelijk is onder meer vanwege het feit dat normen onderhevig zijn aan maatschappelijke veranderingen. Voor de groep waarop de normen betrekking hebben is het vaak eenvoudiger om de ontwikkelingen bij te houden; de groep is dichter bij de ontwikkelingen. Doordat de groep dichter bij de ontwikkelingen staat en zelf afspraken maakt over de regulering zijn de gemaakte afspraken over het algemeen flexibeler en is er een betere acceptatie door betrokkenen. ${ }^{13}$

Een betere acceptatie leidt over het algemeen tot beter nakomen van gemaakte afspraken.

Niet alle onderwerpen komen voor zelfregulering in aanmerking. ${ }^{14}$ Bepaalde onderwerpen zijn exclusief aan de wetgever voorbehouden en komen dus niet voor zelfregulering in 
aanmerking. ${ }^{15}$

Over andere onderwerpen zou gesteld kunnen worden dat de overheid de plicht tot reguleren heeft omdat er een groot maatschappelijk belang in het geding is. ${ }^{16}$

Het is niet zo dat de overheid als enige een taak heeft tot regulering als er een groot maatschappelijk belang in het geding is, maar bij de overheid ligt in elk geval wel de verantwoordelijkheid om het belang te bewaken.

\section{Voorwaarden te stellen aan convenanten}

Convenanten moeten voldoen aan een aantal regels. Deze regels zijn in eerste instantie door Zijlstra geformuleerd in een preadvies. ${ }^{17}$

Naar aanleiding van het genoemde preadvies en een advies van de Commissie Toetsing Wetgevingsprojecten, ${ }^{18}$

zijn de regels waaraan een convenant moet voldoen vastgelegd in de "Vaststelling aanwijzingen voor convenanten" (verder te noemen de Aanwijzing). ${ }^{19}$

De Aanwijzing is een ministeriële aanwijzing en bevat zowel bindende regels als aanbevelingen voor convenanten die door de rijksoverheid worden gesloten. In de Aanwijzing wordt 
uitdrukkelijk gesteld dat het aanbeveling verdient dat de Aanwijzing ook wordt gehanteerd door instellingen buiten de rijksoverheid. ${ }^{20}$

Wat zijn de voorwaarden waaraan een convenant moet voldoen? Ten eerste moet de overheid bevoegd zijn om over het onderwerp een convenant te sluiten. ${ }^{21}$

Een overheid kan geen convenant sluiten over een bevoegdheid die zij niet bezit. Er zijn echter ook bevoegdheden die men gezamenlijk met anderen bezit. Er dient dan op gelet te worden dat de afspraken niet verder gaan dan de eigen bevoegdheid.

Ten tweede moet de overheid beleidsvrijheid of beoordelingsruimte hebben. ${ }^{22}$

De overheid kan zich alleen bewegen binnen de beleidsvrijheid die zij tot haar beschikking heeft. Die beleidsvrijheid kan voortkomen uit de bevoegdheid tot het nemen van beslissingen die aan de overheid zijn toegekend en uit een min of meer vage wettelijke norm die verder dient te worden ingevuld. Bij het invullen van deze norm moet de overheid zich houden aan de vastgestelde procedurele regels. 
Ten derde mag een convenant een publiekrechtelijke bevoegdheid niet onaanvaardbaar doorkruisen. ${ }^{23}$

De afgelopen jaren is er een uitgebreide jurisprudentie ontstaan omtrent de zogeheten tweewegenleer. In het Benckiser-arrest hanteert de Hoge Raad twee criteria voor de mogelijkheid voor privaatrechtelijk overheidsoptreden. ${ }^{24}$

Het eerste criterium is dat, indien de overheid een vergelijkbaar resultaat kan bereiken door het bewandelen van de publiekrechtelijke weg, de privaatrechtelijke weg niet is toegestaan. Het tweede criterium is dat, als het bewandelen van de privaatrechtelijke weg noodzakelijk is vanwege het ontbreken van een publiekrechtelijke weg, de privaatrechtelijke weg geen onaanvaardbare doorkruising mag opleveren van de publiekrechtelijke weg. In het Windmill-arrest worden deze criteria bevestigd. ${ }^{25}$

Ten vierde mag een convenant niet in strijd zijn met het recht. ${ }^{26}$

Strijd met het geschreven recht kan ontstaan als de overheid haar bevoegdheden overdraagt zonder dat 
hiervoor een wettelijke bevoegdheid is. De overheid kan wel haar bevoegdheden beperken door middel van een convenant. Van strijd met rechtsbeginselen is sprake als een convenant bijvoorbeeld burgers in gelijke situaties ongelijk behandeld (gelijkheidsbeginsel) of de overheid zijn publiekrechtelijke bevoegdheden gebruikt voor een ander doel dan waarvoor deze bevoegdheden zijn bedoeld (détournement de pouvoir).

Na deze inleiding over convenanten volgt nu een beschrijving van de convenanten tussen politie en ziekenhuizen zoals die bestaan in Nederland.

\section{- 3. Opzet van het onderzoek}

In dit onderzoek zijn alle traceerbare convenanten tussen politie en ziekenhuizen, die er tussen mei 2002 en september 2002 in Nederland waren, beoordeeld. Om de convenanten te verkrijgen is als volgt te werk gegaan. In eerste instantie zijn het landelijk parket en de verschillende ressorten benaderd met de vraag of er een convenant bestond binnen het ressort. Dit leverde nauwelijks informatie op. ${ }^{27}$

Vervolgens zijn alle ziekenhuizen in Nederland in de periode mei 2002 tot september 2002 benaderd met de vraag of er een convenant bestond tussen het ziekenhuis 
en de politie (en eventueel openbaar ministerie). ${ }^{28}$

\begin{abstract}
Als er een
convenant (of een conceptconvenant) bestond is dit document opgevraagd. Alle benaderde ziekenhuizen waren bereid om mee te werken, zodat gesteld kan worden dat dit onderzoek de stand van zaken weergeeft zoals die was in de periode mei 2002 tot september 2002. Veranderingen na deze periode zijn niet meegenomen in dit onderzoek. Veranderingen tijdens deze periode zijn zoveel mogelijk meegenomen. ${ }^{29}$
\end{abstract}

De verkregen convenanten zijn beoordeeld op de wijze van tot stand komen, 30

het doel van het convenant, de geregelde onderwerpen en per geregeld onderwerp de wijze waarop het onderwerp is geregeld. ${ }^{31}$

Vervolgens zijn de verschillende regelingen met elkaar vergeleken. Ten slotte is beoordeeld of de convenanten in overeenstemming zijn met de Aanwijzing en met 
algemene beginselen van het strafrecht. De Aanwijzing is formeel alleen van toepassing op convenanten van de centrale overheid en een andere partij. Omdat andere instellingen en diensten wordt aanbevolen om de Aanwijzing te volgen, is hier gekozen voor een vergelijking met de Aanwijzing. ${ }^{32}$

\section{- 4. Resultaten van het onderzoek}

In totaal zijn er in Nederland 156 ziekenhuizen. ${ }^{33}$

Door regelmatig voorkomende fusies, sluitingen en naamsveranderingen varieert dit aantal. Van deze 156 ziekenhuizen hebben er 17 geen convenant, 139 ziekenhuizen hebben wel een convenant. Bij deze convenanten zijn één of meer ziekenhuizen betrokken. ${ }^{34}$

zijn er in Nederland 26 convenanten. ${ }^{35}$ 
De convenanten komen voor in alle provincies van Nederland, met uitzondering van de provincie Groningen. Opvallend is dat in het zuiden van Nederland veel meer convenanten zijn gesloten dan in het noorden. In bijvoorbeeld Zuid-Limburg zijn drie convenanten met drie ziekenhuizen gesloten. De grote convenanten (met meer dan zes ziekenhuizen) zijn gesloten in het westen van Nederland en in de provincie Utrecht.

Van de 26 convenanten zullen er twee buiten beschouwing worden gelaten. Van deze twee convenanten had één convenant uitsluitend betrekking op geweld tegen personeel. Eén convenant had uitsluitend betrekking op prikaccidenten. Deze twee convenanten wijken zo ver af van de andere convenanten dat een vergelijking niet meer mogelijk is.

Van de 24 te bespreken convenanten waren er vijf in concept en negentien definitief.

\section{Totst andkoming}

Vaste partijen bij een convenant zijn de politie en minimaal één ziekenhuis. Vaak zijn er echter meerdere ziekenhuizen betrokken bij het convenant. In bijna de helft van de gevallen is ook de GGD betrokken. Dit laatste in verband met de geheimhoudingsplicht van het ambulancepersoneel. Het openbaar ministerie is alleen 
betrokken bij convenanten met meerdere ziekenhuizen. Bij de grote convenanten (met meer dan zes ziekenhuizen) is het openbaar ministerie in de helft van de gevallen betrokken.

Bij de totstandkoming van een convenant wordt regelmatig overlegd met het openbaar ministerie en de Inspectie voor volksgezondheid. ${ }^{36}$

Incidenteel wordt gekozen voor andere instellingen om mee te overleggen dan het openbaar ministerie en de Inspectie voor volksgezondheid. ${ }^{37}$

In de helft van de gevallen wordt niet met anderen dan de betrokken partijen overlegd.

\section{Doel}

De convenanten zijn, naar mag worden aangenomen, met een bepaald doel tot stand gekomen. Echter in slechts drie gevallen wordt het doel expliciet beschreven. In de andere gevallen is het doel te destilleren uit de inleiding of de "overweging vooraf". In drie gevallen wordt geen doel vermeld en is een doel evenmin af te leiden uit de 
“overwegingen vooraf"of de inleiding. Vaak worden ook meerdere doelen vermeld.

Als doel van een convenant worden genoemd: het duidelijk maken van wederzijdse belangen (16x), het maken van procedureafspraken (18x), het bevorderen van de communicatie (4x) en informatie-uitwisseling (4x).

Bij het totstandkomen van een convenant wordt in de helft van de gevallen een contactpersoon in het ziekenhuis en/ of bij de politie aangesteld. De contacten tussen politie en het ziekenhuis dienen te verlopen via deze contactpersonen. Als bijzonderheid kan vermeld worden dat in twee gevallen ook bij het openbaar ministerie een contactpersoon wordt ingesteld, terwijl het openbaar ministerie geen partij is bij het convenant.

\section{Onderwerpen}

In het onderstaande zal kort worden besproken over welke onderwerpen in de convenanten afspraken zijn gemaakt.

Vele convenanten bevatten een passage over de omvang en de betekenis van het beroepsgeheim. In de convenanten wordt uitgelegd, dat een medewerker van het ziekenhuis een beroepsgeheim heeft en dat het belang van het beroepsgeheim prevaleert boven het belang van opsporing. In een groot aantal convenanten wordt 
daaraan toegevoegd dat het beroepsgeheim niet absoluut is. Het conflict van plichten en de criteria van Leenen om het beroepsgeheim te doorbreken worden vaak genoemd. 38

Over het beroepsgeheim blijkt niet veel verschil van mening te bestaan. Wel is er een aanzienlijk verschil in omvang van de regeling; de omvang varieert van zeer summier (enkele regels) tot uitgebreid (een pagina).

Informatieverstrekking bij een ongeval is in alle convenanten op dezelfde wijze geregeld. Informatie over de identiteit en medische informatie over de (slachtoffer)patiënt mag worden gegeven na toestemming van de (slachtoffer)patiënt. Toestemming mag worden verondersteld als de (slachtoffer)patiënt geen toestemming kan geven. Informatie dient door de politie opgevraagd te worden met het KNMG-formulier informatieverstrekking.

Ook informatieverstrekking bij opsporingsactiviteiten is eenduidig geregeld. Aan politie wordt geen informatie verstrekt over de aanwezigheid of de identiteit van de dader. Evenmin wordt er medische informatie verstrekt indien de dader in het ziekenhuis wordt behandeld. Een 
uitzondering op deze regel wordt gemaakt als de dader toestemming verleent tot het geven van informatie aan de politie. Toestemming mag niet verondersteld worden als de patiënt (verdachte) die niet zelf kan geven.

Over het betreden van het ziekenhuis zijn in de convenanten vele verschillende procedures beschreven. In zeventien convenanten wordt geregeld dat een politieagent zich eerst moet melden en de reden van zijn komst moet aangeven. In vier convenanten is geen enkele regeling opgenomen ten aanzien van binnentreden of het huisrecht. 39

In drie convenanten wordt gesteld dat het huisrecht geldt voor het gehele ziekenhuis; in twee van de drie convenanten wordt gesteld dat er dan ook toestemming dan wel een machtiging tot binnentreden nodig is. In het derde geval wordt niet over de noodzaak van een machtiging, bij het ontbreken van toestemming, gesproken.

In zeventien convenanten wordt gesteld dat een ziekenhuis een gedeeltelijk openbaar gebouw is. De hal en 
de gangen van het ziekenhuis worden dan beschouwd als vrij toegankelijk voor een ieder; dus ook voor een politieagent.

Voor de behandelkamer wordt in geen enkel geval een huisrecht vastgesteld; met uitzondering van de convenanten die voor het gehele ziekenhuis huisrecht vaststellen. Wel wordt in elf convenanten gesteld dat toestemming van de behandelaar en de patiënt nodig is; in vier gevallen kan volgens het convenant worden binnengetreden met een machtiging als geen toestemming is gegeven.

In de zaal waar de patiënt verblijft wordt in drie convenanten de privacy van de patiënt beschermd door het huisrecht; in twee van deze convenanten wordt geregeld dat bij ontbreken van toestemming met een machtiging kan worden binnengetreden.

In twee convenanten wordt geregeld dat er sprake is van huisrecht in een kamer die te beschouwen is als privé verblijf. Wat een privé-verblijf is wordt niet verder uitgelegd; toestemming of een machtiging is in deze situatie noodzakelijk. In één convenant wordt gesteld, dat een machtiging tot binnentreden nodig is voor vertrekken, die als woning te beschouwen zijn. Niet duidelijk is welke vertrekken dat zijn. 
Zoals gezegd zijn er op het gebied van het binnentreden zeer veel verschillende regelingen; de verschillende regelingen munten niet uit in helderheid.

Over de bevoegdheid tot afgifte van de verschillende soorten machtigingen bestaat in de convenanten onduidelijkheid. Respectievelijk de officier van justitie, de rechter commissaris of de burgemeester zijn volgens de convenanten bevoegd tot afgifte van de machtigingen.

Aanhouden en horen dienen bij voorkeur plaats te vinden buiten het ziekenhuis en dienen medisch verantwoord te zijn; dit is de lijn die in vrijwel alle convenanten wordt gevolgd. Van horen dient te worden afgezien als de medische toestand van de patiënt het niet toelaat. Eén convenant regelt dat een patiënt toestemming moet geven als horen medisch niet verantwoord is. ${ }^{40}$

Voor het horen van een patiënt dient volgens bijna alle convenanten toestemming van de patiënt gevraagd te worden. Zonder deze toestemming zou horen niet mogelijk zijn. In twee convenanten is geregeld dat horen ook mogelijk is zonder toestemming van de patiënt.

Ongeveer de helft van de convenanten heeft een regeling opgenomen over inbeslagneming. Een machtiging tot 
inbeslagneming is daarvoor noodzakelijk. In twee convenanten is geregeld dat het medisch dossier in beslag genomen kan worden. Volgens elf convenanten kan het medisch dossier niet in beslag genomen worden. Dertien convenanten hebben hieromtrent geen regeling opgenomen.

Voorwerpen kunnen volgens acht convenanten in beslag worden genomen. Laboratoriummateriaal of lichaamsmateriaal kan volgens drie convenanten niet en volgens twee convenanten wel in beslag genomen worden.

De onduidelijkheid die heerst over het binnentreden blijkt ook te bestaan over inbeslagneming.

In 21 convenanten is een regeling opgenomen over onnatuurlijke dood. Een aantal convenanten geeft uitleg over wanneer er sprake is van een onnatuurlijke dood. De meeste convenanten maken onderscheid tussen de situatie dat er direct twijfel is aan een natuurlijke doodsoorzaak en de situatie dat deze twijfel ontstaat bij een klinische obductie.

Alle convenanten houden dezelfde lijn aan in de eerst genoemde situatie; bestaat de twijfel omtrent een al dan niet natuurlijke dood al direct dan dient de gemeentelijke lijkschouwer gewaarschuwd te worden. ${ }^{41}$ 
Ontstaat de twijfel tijdens een klinische obductie dan dient volgens zestien convenanten wederom de gemeentelijk lijkschouwer gewaarschuwd te worden. In vier convenanten staat vermeld dat het openbaar ministerie op de hoogte gebracht moet worden. In één convenant is geregeld dat de politie en de forensisch geneeskundige gewaarschuwd dienen te worden.

In een groot aantal convenanten is geregeld hoe omgegaan dient te worden met het vinden van drugs en wapens. De regeling is eenduidig; in beide gevallen dienen de "gevonden voorwerpen" anoniem aan de politie te worden overgedragen. In één convenant wordt enkel gesteld dat het vinden van drugs onder het beroepsgeheim valt. Verder wordt niet duidelijk gemaakt wat de hulpverlener moet doen met de voorwerpen.

In veertien convenanten wordt een procedure beschreven over hoe te handelen als iemand slachtoffer is van seksueel geweld. Het protocol bevat een regeling over het afnemen van materiaal voor opsporingsonderzoek en voor de aangifte bij de politie. Het materiaal wordt afgenomen door de forensisch geneeskundige. Aangifte van het strafbare feit is alleen mogelijk met toestemming van de patiënt. 
In vijftien convenanten is een regeling opgenomen over hoe men dient om te gaan met een (ernstig) vermoeden van kindermishandeling. In vrijwel alle convenanten is de regeling summier. Gesteld wordt dat het optreden van de hulpverlener afhangt van de omstandigheden en dat aangifte bij de politie niet altijd de beste keuze is. In een groot aantal convenanten wordt aangegeven dat het probleem serieus genomen moet worden. Ook wordt in een aantal convenanten geadviseerd om contact op te nemen met de politie. Opvallend is dat slechts in vier convenanten melding wordt gemaakt van het Advies en Meldpunt Kindermishandeling (met telefoonnummer) ${ }^{42}$

Ook voor geweld tegen de hulpverlener is in de meeste convenanten een regeling vastgesteld. In principe kan aangifte gedaan worden. Vaak kan de hulpverlener het ziekenhuis als residentie opgeven. ${ }^{43}$

De regelingen over seksuele delicten en geweld tegen hulpverleners komen in alle convenanten sterk overeen.

Bewaken van verdachten en getuigen of slachtoffers is eenduidig geregeld in de convenanten. Bewaken dient in overleg met de directie (en over het algemeen de 
contactfunctionaris) van de instelling te gebeuren. Details over de uitvoering van de bewaking zijn niet geregeld.

De bloedproef in verband met alcoholgebruik is in alle convenanten op dezelfde wijze geregeld, namelijk in overeenstemming met de wet. De bloedafname en de afname van materiaal voor DNA-onderzoek moet gedaan worden door de forensisch geneeskundige.

Een aantal convenanten bevat naast deze regelingen nog een uitleg over de positie van de forensisch geneeskundige.

In tien convenanten is opgenomen dat na een jaar een evaluatie zal plaats vinden. In enkele convenanten is een commissie in het leven geroepen om de problemen met het hanteren van een convenant te registreren.

\section{- 5. Krit ische noot bij de convenanten}

Het eerste dat opvalt is dat er convenanten tussen politie en ziekenhuis zijn ontstaan. Alvorens tot het sluiten van een convenant over te gaan moet overwogen worden of er niet beter voor regelgeving door de overheid kan worden gekozen. ${ }^{44}$ Het lijkt er sterk op dat deze vraag bij het sluiten van de convenanten niet aan de orde is geweest. Opsporing in ziekenhuizen was een probleem en de oplossing werd gezocht in convenanten. De vraag of de wettelijke regels veranderd moesten worden is niet aan de 
orde geweest. De vraag of de afspraken die gemaakt worden in het convenant de publiekrechtelijke bevoegdheid (in casu de strafrechtelijke bevoegdheden) van de overheid niet onaanvaardbaar doorkruisen is evenmin aan de orde geweest.

Het tweede dat opvalt is dat in een groot aantal convenanten geen doel geformuleerd is. Dit is in strijd met de Aanwijzing. ${ }^{45} \quad$ Bovendien wordt het mijns inziens bijzonder moeilijk om een convenant te evalueren als er geen doel is bepaald; evaluatie dient immers om vast te stellen of de gestelde doelen zijn gehaald. ${ }^{46}$

Het derde dat opvalt bij het bekijken van de convenanten is dat het blijkbaar mogelijk is om over een bepaalde materie zoveel verschillende regels te maken. Om een voorbeeld te noemen: de regelingen over binnentreden en inbeslagneming die voorkomen in de convenanten zijn zo divers dat het bijna niet mogelijk is de regelingen te groeperen. Deze diversiteit aan regels leidt tot vragen. Kan een politieregio of een arrondissementsparket zijn eigen regeling maken op het gebied van strafvordering? Zijn deze regels bindend? Wat te doen als deze afspraken in strijd met de wet zijn? En wie kan zich beroepen op deze afspraken? 
Ik zal pogen om op een aantal van deze vragen antwoord te geven of de twijfel te formuleren.

\section{Beleidsvrijheid}

Kan een politieregio of arrondissementsparket zijn eigen regeling maken op het gebied van strafvordering? Of, anders gesteld, heeft de politie de bevoegdheid en beleidsvrijheid om afspraken te maken over strafvordering? Bevoegdheid en beleidsvrijheid zijn immers de eerste twee voorwaarden waaraan een convenant moet voldoen. ${ }^{47}$

De Grondwet (Gw) en het Sv lijken op het eerste gezicht duidelijk over deze vraag. In artikel $107 \mathrm{Gw}$ ligt vast dat de wet het strafrecht regelt. In artikel $1 \mathrm{~Sv}$ wordt deze regel verder uitgewerkt. Artikel 1 Sv stelt dat strafvordering alleen plaats vindt op de wijze bij de wet voorzien. Artikel 1Sv moet niet alleen gezien worden als een bevoegdheidstoekenning (constitutief), maar ook als bevoegdheidsbeperking (limitatief). ${ }^{48}$

Het is met andere woorden niet mogelijk om de strafvorderlijke bevoegdheden van een opsporingsambtenaar uit te breiden met bevoegdheden die niet staan beschreven in het Sv of een andere formele wet. 
Is het beperken van strafvorderlijke bevoegdheden dan wel mogelijk? Kunnen de politie en het openbaar ministerie afspreken dat zij hun strafvorderlijke bevoegdheden niet gebruiken? In principe lijkt dit wel mogelijk; strafvorderlijke bevoegdheden zijn bevoegdheden en geen plichten. Desalniettemin kleven er problemen aan het beperken van strafvorderlijke bevoegdheden. Om te beginnen kan de politie alleen afspraken maken over haar eigen bevoegdheden en niet over de bevoegdheden van het openbaar ministerie. 49 Het is zelfs de vraag of de politie haar bevoegdheden zonder medeweten van het openbaar ministerie kan beperken. Bij het verrichten van taken ten behoeve van justitie staat de politie immers onder het gezag van het openbaar ministerie (art. $148 \mathrm{~Sv}$ en art. 13 Politiewet 1993). Dat betekent dat de opsporingsambtenaar opdrachten ten aanzien van opsporing kan krijgen van de officier van justitie. Indien de opdrachten in strijd zijn met de afspraken die de politie heeft gemaakt met een ziekenhuis, dient de politieagent de opdrachten niettemin uit te voeren.

Ten overvloede vermeld ik dat de politie en het openbaar ministerie geen afspraken kunnen maken die de bevoegdheden van de rechter commissaris beperken.

\section{Bindende afspraken?}


Het bovenstaande leidt tot nieuwe vragen. Zijn de afspraken die worden gemaakt tussen politie, openbaar ministerie en ziekenhuizen bindend?

Deze vraag heeft betrekking op de derde en vierde voorwaarde door Zijlstra genoemd voor het maken van een convenant. 50 De gemaakte afspraken mogen niet in strijd met de wet zijn. Het gevolg van strijd met de wet is dat de afspraken nietig zijn. Van strijd met de wet is sprake als strafvorderlijke bevoegdheden in een convenant ruimer worden geformuleerd dan in het Wetboek van Strafvordering. Strafvorderlijke bevoegdheden die ruimer zijn geformuleerd dan in het Wetboek van Strafvordering zijn immers in strijd met artikel 1Sv. Van strijd met de wet is tevens sprake als in een convenant een machtiging (tot binnentreden) noodzakelijk wordt geacht, terwijl de wet deze eis niet stelt. Ten slotte is er sprake van strijd met de wet als in een convenant een machtiging door een andere autoriteit noodzakelijk wordt geacht dan in het Wetboek van Strafvordering is vastgelegd. Zonder volledig te willen zijn noem ik enkele afspraken in convenanten die in strijd met de wet zijn. Afspraken waardoor de mogelijkheid van inbeslagneming van medische dossiers wordt gecreëerd, ${ }^{51}$ 
afspraken dat bij het vaststellen van een onnatuurlijke dood de politie of het openbaar ministerie moet worden gewaarschuwd ${ }^{52}$

en afspraken dat de burgemeester een machtiging tot binnentreden kan afgeven. 53 
Afspraken tussen ziekenhuizen, politie en openbaar ministerie die in strijd met de wet zijn kunnen, hoewel ze nietig zijn, overigens wel voor verwarring zorgen. ${ }^{54}$

Eén van de doelen van de convenanten, namelijk duidelijkheid scheppen over bevoegdheden, wordt met dergelijke verwarrende afspraken ondergraven.

\section{Afdwingbare afspraken?}

Zijn de afspraken in convenanten afdwingbaar? In de convenanten worden geen mededelingen gedaan over de mate van afdwingbaarheid van de afspraken. Enkele convenanten vermelden dat een deel van het convenant informatief is en dat er geen rechten kunnen worden ontleend aan het informatieve deel van het convenant. Deze convenanten wekken de indruk "gentlemen's agreements" te zijn. Onder een gentlemen's agreement wordt een niet bindende afspraak tussen twee partijen verstaan. 55

Het feit dat partijen geen binding op het oog hadden, betekent overigens niet dat er geen overeenkomst tot stand is gekomen; alleen de nakoming is niet afdwingbaar. 
Van de overige convenanten is niet vast te stellen of deze in rechte afdwingbaar zijn.

Vanwege strijd met de wet zijn (delen van) afspraken in convenanten niet bindend.

Maar indien (delen van) afspraken in convenanten bindend zijn, wie kan zich dan beroepen op de afspraken die gemaakt worden? In principe is een privaatrechtelijke overeenkomst alleen bindend tussen partijen (art. 6:248257 BW). Dat betekent dat zowel het ziekenhuis als de politie zich kan beroepen op de afspraken in de convenanten. Schending van een convenant levert wanprestatie op.

Partijen die zich in een convenant hebben gebonden aan afspraken kunnen zich op die afspraken beroepen, maar geldt dit ook voor derden? Bij de convenanten tussen politie en ziekenhuizen is sprake van een niet onbelangrijke derde, namelijk de patiënt. Belangen van derden moeten worden gewogen bij de totstandkoming van een convenant. ${ }^{66} \quad$ Het convenant is gesloten met het doel het beroepsgeheim van de hulpverlener te garanderen en het beroepsgeheim draait om het geheim van de patiënt. Kan de patiënt zich beroepen op de gemaakte afspraken? Een patiënt moet, bij het aangaan van de behandelingsovereenkomst, op de hoogte zijn van de afspraken die het ziekenhuis met de 
politie maakt; een convenant moet dus kenbaar zijn voor de patiënt. De patiënt moet weten wat hij in zijn verhouding tot het ziekenhuis en de arts mag verwachten..$^{57}$

In het protocollenarrest werd door de Hoge Raad gesteld dat een protocol niet slechts een interne afspraak is, maar dat een patiënt zich kan beroepen op een protocol. Een vergelijkbare redenering is mogelijk voor een convenant tussen politie en ziekenhuizen. Een convenant is weliswaar een afspraak tussen de politie en een ziekenhuis en niet zoals een protocol alleen een interne afspraak, toch bevat een convenant afspraken over hoe gehandeld zal worden in een bepaalde situatie. Het gevolg van het bovenstaande is dat indien gehandeld wordt in strijd met een convenant een patiënt zich op het convenant kan beroepen, tenzij het convenant in strijd is met de wet.

\section{Onrecht matig verkregen bewijs}

Indien door schending van de afspraken in een convenant informatie wordt verkregen door de politie die zonder schending van het convenant niet zou zijn verkregen is het bewijs dan onrechtmatig verkregen? Bewijs dat door de justitie op onrechtmatige wijze is verkregen kan van gebruik worden uitgesloten. Maar is het niet nakomen van een privaatrechtelijke overeenkomst door justitie 
voldoende om te spreken over onrechtmatig verkregen bewijs in strafrechtelijke zin?

Indien het openbaar ministerie of de politie afspraken maken over strafvorderlijke bevoegdheden en deze afspraken worden niet nagekomen is dit mijns inziens schending van het vertrouwensbeginsel. ${ }^{58}$

Het vertrouwensbeginsel houdt in dat de overheid de opgewekte verwachtingen in redelijkheid dient na te komen, tenzij zwaarwichtige redenen zich daartegen verzetten. 59

In verschillende arresten is dit beginsel door de Hoge Raad erkend. ${ }^{60}$

In deze arresten heeft het schenden van het vertrouwensbeginsel geleid tot het verlies van het vervolgingsrecht door het openbaar ministerie. Voorwaarde voor een beroep op het vertrouwensbeginsel is volgens de Hoge Raad dat het vertrouwen moet zijn gewekt door het openbaar ministerie. ${ }^{61}$ Ik wil mij echter aansluiten bij de mening van Corstens. Hij is van mening dat het vertrouwensbeginsel ook zou moeten gelden voor toezeggingen van ambtenaren van politie. ${ }^{62}$ 
Het lijkt mij op grond van het voorgaande dan ook mogelijk om tot het oordeel te komen dat bewijs, dat is verkregen door het gebruik van strafvorderlijke bevoegdheden in strijd met een convenant, in strafrechtelijke zin onrechtmatig verkregen is. Of dit in het voorkomende geval ook betekent dat bewijs, dat wordt verkregen doordat in strijd met een convenant wordt gehandeld, in een strafproces van gebruik wordt uitgesloten is niet duidelijk. Een rechterlijke uitspraak laat nog op zich wachten.

\section{Recht songelijkheid}

Een ander probleem is de rechtsongelijkheid die ontstaat door de verschillende convenanten die bestaan in Nederland. De verschillende convenanten betekenen dat de patiënt in een ziekenhuis voor zijn rechtsbescherming afhankelijk is van de afspraken die het ziekenhuis heeft gemaakt met justitie. Dit is in strijd met het gelijkheidsbeginsel. Het gelijkheidsbeginsel wil zeggen dat gelijke gevallen gelijk behandeld moeten worden. Bij optreden in het kader van strafrecht is het vaak moeilijk om te spreken van "gelijke gevallen". Dit maakt dat het gelijkheidsbeginsel in het strafrecht moeilijk te toetsen is. 63 
Maar het is zeker niet de bedoeling om op voorhand al verschillende afspraken te maken over het gebruik van een zelfde strafvorderlijke bevoegdheid.

Niet alleen vanuit strafrechtelijke optiek, maar ook vanuit gezondheidsrechtelijk oogpunt kan kritiek worden geuit op de grote diversiteit aan convenanten. Door de verschillende afspraken die worden gemaakt is de rechtsbescherming van patiënten afhankelijk van deze afspraken. De patiënt bevindt zich in een ziekenhuis in een bijzondere (kwetsbare) privé-situatie. Het privé-leven van de patiënt zou dan ook in elk ziekenhuis op dezelfde wijze beschermd moeten worden. Bovendien moet de gezondheidszorg vrij toegankelijk zijn voor eenieder. De toegankelijkheid kan niet afhankelijk zijn van de al dan niet criminele achtergrond van de patiënt en ook niet van de afspraken die het ziekenhuis maakt met justitie.

Bescherming van het privé-leven van de patiënt en toegankelijkheid van de zorg zijn de twee belangen die door het beroepsgeheim gediend worden. ${ }^{64}$

De verschillende afspraken die gemaakt worden tussen politie en ziekenhuizen lijken inbreuk te maken op deze belangen. Ook in dit opzicht schieten de convenanten dus hun doel voorbij.

\section{- 6. Conclusie}


In dit artikel heb ik een overzicht gegeven van de verschillende convenanten die tot stand zijn gekomen tussen politie en ziekenhuizen in Nederland. Hoewel een groot aantal ziekenhuizen in Nederland een convenant met politie (en openbaar ministerie) heeft gesloten, is er een aantal kritische vragen te stellen over het totstandkomen van deze overeenkomsten.

Uit de convenanten blijkt onvoldoende wat het doel is en of juridische binding is beoogd. Dit leidt tot onduidelijkheid en verwarring.

Van bepaalde afspraken in convenanten kan gesteld worden dat deze nietig zijn omdat zij in strijd zijn met de wet. Het is met andere woorden niet mogelijk om afspraken te maken in convenanten over strafvorderlijke bevoegdheden die in strijd zijn met het Wetboek van Strafvordering.

Afspraken die betrekking hebben op bevoegdheden die niet liggen bij een contractspartij zijn niet bindend. De politie kan geen afspraken maken over de bevoegdheden van het openbaar ministerie en het openbaar ministerie kan geen afspraken maken over de bevoegdheden van de rechter-commissaris. Het is zelfs de vraag of de politie afspraken kan maken over haar eigen bevoegdheden buiten medeweten van het openbaar ministerie om. 
Opvallend zijn de grote inhoudelijke verschillen tussen de convenanten. Zowel vanuit strafrechtelijk als vanuit gezondheidsrechtelijke optiek zijn deze inhoudelijke verschillen niet wenselijk. Door deze verschillen tussen de convenanten wordt niet alleen het gelijkheidsbeginsel geschonden, maar komt tevens de privacybescherming van de patiënt en de toegankelijkheid van de gezondheidszorg in het gedrang.

Het is de vraag of handelen in strijd met een convenant, hetgeen mijns inziens een schending van het vertrouwensbeginsel is, onrechtmatig verkregen bewijs kan opleveren.

Ten slotte is onduidelijk wie zich op een convenant kan beroepen; zijn dat de partijen of ook relevante derden, zoals patiënten?

De convenanten zijn bedoeld om een oplossing te zoeken voor de botsing tussen opsporingsbelang en het medisch beroepsgeheim. Al met al lijken er meer vragen dan antwoorden voort te komen uit deze uiting van het oerHollandse poldermodel. 
- 1F. Velling-Schootstra, Inbeslagneming en huiszoeking, Alphen aan den Rijn: Samsom H.D. Tjeenk Willink 1982, p. 170.

- 2 HR 30 november 1999, 270 en NJ 2002, 438 (m.nt. YB) en HR 12 februari 2002, NJ 2002, 439 (m.nt. YB).

- 3 Zie bijvoorbeeld Rechtbank Zwolle, 4 december 1998, TvGR 1999, 20 en HR 25 september 2001, TvGR 2002, 37.

- 4 Er bestaan niet alleen convenanten tussen politie en ambulancezorg, maar ook tussen politie, ziekenhuizen en ambulancezorginstellingen. De convenanten tussen politie, ziekenhuizen en ambulancezorg zijn meegenomen in het onderzoek.

- 5 Richtlijn “Beroepsgeheim en uitwisseling van gegevens tussen ambulancezorg, politie en openbaar ministerie", te raadplegen op www.ambulancezorg.nl, p.1.

- 6 Kamerstukken II 1992/93, 22 800VI, nr. 4, p. 5.

- 7J .M. Polak, "Aanwijzingen voor zelfregulering?”, in:

J.G. Steenbeek (red.), Bestuur en norm, Deventer: Kluwer 1986, p. 217.

- 8 Commissie voor de toetsing van wetgevingsprojecten, Convenanten, p. 5. F.J . van Ommeren, "Convenanten in soorten en maten op weg naar de reguleringsovereenkomst", in: F.J. van Ommeren en H.J . de Ru (red.), Convenanten tussen overheid en 
maatschappelijke organisaties, 's-Gravenhage: Sdu juridische en fiscale uitgeverij 1993, p. 29.

- 9 Een duidelijk voorbeeld hiervan is de Wet toetsing levensbeëindiging op verzoek en hulp bij zelfdoding. De totstandkoming van deze wet heeft enkele tientallen jaren geduurd. In de tussentijd is er een euthanasiepraktijk ontstaan. Deze praktijk was gebonden aan regels door het medische werkveld opgesteld. Deze wijze van handelen werd ook door de rechter geaccepteerd.

- 10 F.J . van Ommeren, "Convenanten in soorten en maten”, in: F.J . van Ommeren en H.J . de Ru (red.), Convenanten tussen overheid en maatschappelijke organisaties, 's-Gravenhage: Sdu juridische en fiscale uitgeverij 1993, p. 41.

- 11 Een voorbeeld hiervan is de Wet klachtrecht cliënten zorgsector. In art. 2 is aan elke zorgaanbieder de opdracht gegeven om een regeling te treffen voor de behandeling van klachten.

- 12 L.M.C. Faro, De kwaliteit van implantaten in juridisch perspectief (diss.), Rotterdam: Erasmus Universiteit 1990, p. 162.

- 13 W.R. Kastelein, Van klagen tot klachtrecht (2e druk), Arnhem: Gouda Quint B.V. , p. 315.

- 14 Faro 1990, p. 163 (zie noot 13).

- $15 \mathrm{Zo}$ is in art. $1 \mathrm{~Sv}$ vastgelegd dat strafvordering alleen plaatsvindt op de wijze bij de wet bepaald. 
- 16 Faro 1990, p. 163-165 (zie noot 13).

- 17 S.E. Zijlsta, Preadvies Convenanten, Zwolle: W.E.J . Tjeenk Willink 1994.

- 18 CTW 92/2, d.d. 10 april 1992.

19 Vaststelling aanwijzingen convenanten, Stcrt. 1995, nr. 249, p. 32 (Aanwijzing).

- 20 Aanwijzing, toelichting op artikel 1.

- 21Zijlstra 1994, p. 26-29. Aanwijzing 9 (zie noot 18).

- 22 Zijlstra, 1994, p. 29-31 (zie noot 18).

- 23 Zijlstra 1994, p. $32-36$ (zie noot 18). HR 26 januari 1990, AB 1990, 408, NJ 1991, 393, HR 9 juli 1990, AB 1990, 547, NJ 1991, 394 en HR 22 oktober 1993, AB 1994, 1.

- 24 HR 14 april 1989, NJ 1990, 712, AB 1989, 486 (Benckiser).

- 25 HR 9 juli 1990, NJ 1991, 394, AB 1990, 547 (Windmill). J.E.M. Polak, Burgerlijke rechter of bestuursrechter?, Deventer: Kluwer 1999, p. 107-108.

- 26 Zijlstra 1994, p. 37-40. Aanwijzing 10 (zie noot 18).

- 27 Het landelijk parket was niet op de hoogte van de convenanten. Op ressortniveau bestond onduidelijkheid over het al dan niet bestaan van een convenant.

- 28 Bij bepaalde convenanten zijn meerdere ziekenhuizen betrokken. Als het convenant al verkregen was van een ander ziekenhuis zijn de andere betrokken ziekenhuizen niet meer benaderd. 
- 29 Te denken valt aan een conceptconvenant dat definitief wordt of een convenant dat na evaluatie wordt bijgesteld.

- 30 Betrokken partijen en partijen waarmee is overlegd.

- 31R.A. van de Peppel en M. Herweijer, "Convenanten in soorten", NJ B 1993, afl. 14, p. 489-494. Volgens van de Peppel en Herweijer moet uiteindelijk een antwoord worden gegeven op de volgende vragen:

o Wat is het motief om een convenant te sluiten?

o Voor welk instrument vormt het convenant een alternatief?

o Wat wordt er in het convenant geregeld?

o Hoe worden de convenanten nageleefd?

- 32 Zie “Aanwijzingen convenanten”, p. 1. Zie ook F.B.M. Olijslager, "Samenwerkingsconvenant politie en ziekenhuizen”, Beveiliging nr. 2, jaargang 10 (2000), p. 12-14.

- 33 De Nederlandse vereniging van ziekenhuizen heeft 156 leden, ingeschreven per ziekenhuislocatie, psychiatrische ziekenhuizen meegerekend.

- 34 Regelmatig zijn ook andere partijen betrokken, zoals het openbaar ministerie, GGD en ambulancediensten.

- 35 Verder zijn er nog een aantal ziekenhuizen bezig om een convenant te maken. Deze ziekenhuizen gaven aan nog in de "beginfase" te zijn; er was dan ook nog geen 
sprake van een conceptconvenant. Deze "aanzetten tot convenanten" zijn buiten beschouwing gelaten.

- 36 Van overleg met het openbaar ministerie is sprake, als het openbaar ministerie wel betrokken is bij de totstandkoming, maar geen partij is.

- 37 Andere partijen zijn onder meer een penitentiaire inrichting, SIGG en SIGRA. SIGG = Stichting samenwerkende instellingen voor gezondheidszorg in het Gooi en de Vechtstreek e.o. SIGRA = Stichting samenwerkende instellingen gezondheidszorg Amsterdam.

- 38 H.J .J . Leenen/J .K.M. Gevers, Handboek gezondheidsrecht, Deel I. Rechten van mensen in de gezondheidszorg (4e, geheel herziene druk), Houten/ Diegem: Bohn Stafleu Van Loghum 2000, p. 234.

- 39 Het huisrecht is het recht op een privaat huiselijk leven. Onder omstandigheden kan het huisrecht ook gelden in (gedeelten) van openbare gebouwen. Het huisrecht wordt onder andere beschermd door art. 8 EVRM. Het recht houdt in dat zonder toestemming van een bewoner een woning niet betreden mag worden. Slechts een formele wet kan op dit recht een inbreuk maken. 
- 40 Het lijkt in deze regeling alsof toestemming het oordeel van de arts, of horen al dan niet medisch verantwoord is, kan vervangen.

- 41 Andere namen die worden gebruikt voor de gemeentelijke lijkschouwer zijn de GGD-arts en forensisch geneeskundige.

- 42 Dit is te meer opvallend omdat er in 2001 een landelijke campagne is geweest om de AMK's (Advies en Meldpunt Kindermishandeling) bekendheid te geven.

- 43 Dit om de veiligheid van het ziekenhuispersoneel te garanderen.

- 44 Aanwijzing 4.

- 45 Aanwijzing 9.

- 46 Aanwijzing 18.

- 47 Aanwijzing 10.

- 48 C.P.M. Cleiren, art. 1, aant. 3, Suppl. 89 (juli 1994), in: Melai/Groenhuijsen, Wetboek van Strafvordering.

- 49 Aanwijzing 6.

- 50 Zie ook Aanwijzing 4 en 10.

- 51Zoals uit het onderzoek blijkt wordt in drie convenanten geregeld dat het mogelijk is om het medisch dossier dan wel medische informatie in beslag te nemen. Dit is in strijd met art. $98 \mathrm{~Sv}$ waarin wordt gesteld dat geschriften tot welke de plicht tot geheimhouding zich uitstrekt, niet in beslag kunnen worden genomen. Op deze regel is in de jurisprudentie een uitzondering 
geformuleerd, namelijk indien de hulpverlener verdacht is van een ernstig strafbaar feit, is inbeslagneming van het medisch dossier mogelijk. Zie HR 30 november 1999, 270 en NJ 2002, 438 (m.nt. YB); HR 12 februari 2002, NJ 2002, 439 (m.nt. YB). Deze uitzondering kan zeker niet als hoofdregel worden vastgelegd in een convenant. Deze uitzondering kan zeker niet als hoofdregel in een convenant worden vastgelegd.

- 52 Uit het onderzoek blijkt dat in vier convenanten is geregeld dat bij vaststelling van een onnatuurlijke dood het openbaar ministerie moet worden gewaarschuwd. In één convenant is geregeld dat in deze situatie zowel de politie als het openbaar ministerie op de hoogte moeten worden gebracht. Beide afspraken zijn in strijd met art. 7 van de Wet op de lijkbezorging en zijn een onnodig grote schending van het medisch beroepsgeheim.

- 53 In enkele convenanten is geregeld dat de machtiging tot binnentreden kan worden afgegeven door de burgemeester. Volgens art. 3 Algemene wet op het binnentreden dient een machtiging tot binnentreden te worden afgegeven door een officier van justitie.

- 54 Van de gemiddelde hulpverlener in een ziekenhuis kan immers niet verwacht worden dat hij weet of een gemaakte afspraak al dan niet in strijd met de wet, en dus nietig, is. 
- 55 Zijlstra 1994, p. 23 (zie noot 18) en Hof Arnhem 4 januari 1949, NJ 1949, 581.

- 56 Aanwijzing 12.

- 57 Zie het protocollenarrest, HR 2 maart 2001, NJ 2001, 649 (m.nt. J BMV).

- 58 Voorwaarde voor een beroep op het vertrouwensbeginsel is dat het convenant openbaar is. Dat wil zeggen dat de afspraken te kennen moeten zijn voor een ieder.

- 59 G.J .M. Corstens,, Het Nederlands strafprocesrecht (4e druk), Deventer: Gouda Quint 2002, p. 62-63.

- 60 HR 15 juni 1882, NJ 1983, 216, HR 13 september 1983, NJ 1984, 151 (m.nt. P.J.P. Tak).

- 61 HR 13 september 1988, NJ 1989, 403.

- 62 Corstens 2002, p. 64 (zie noot 60).

- 63 De Hoge Raad is toetsing overigens in het verleden niet uit de weg gegaan. Zie HR 24 juni 1980, NJ 1981, 659 (m.nt. J AB), HR 30 mei 1989, NJ 1889, 883 (m.nt.) 'tH, HR 22 oktober 1991, NJ 1992, 282 (m.nt. 'tH) en HR 13 januari 1998, NJ 1998, 407.

- 64 Leenen/Gevers 2000, p. 222 (zie noot 39). 